Science Life

\title{
STATE STENDE CEREAL BREEDING INSTITUTE: FROM THE ORIGINS TO THE PRESENT
}

\author{
Sanita Zute, Ina Belicka, and Zigurds Kalmanis \\ State Stende Cereal Breeding Institute, "Dižzemes", Dižstende, Lībagu pag., Talsu nov., LV-3258, LATVIA \\ sanita.zute@stendeselekcija.Iv
}

\begin{abstract}
Agricultural science is closely linked to circumstances and specific features of development in each region. The State Stende Breeding Station, the first breeding station in independent Latvia, was founded ninety years ago with a goal to raise agricultural production in the country. The Stende Breeding Station was engaged in selection of crop varieties suitable for Latvian conditions, providing farmers with high-quality seeds and knowledge on the cultivation of these varieties. During the years of its existence, the station has witnessed changes in political power, underwent different forms of management and operated under various names. A number of outstanding scientists and agronomists have worked at Stende, including J. Lielmanis, E. Bērzinš, J. Garbars, N. Konrāds, R. Kude, I. Celma, I. Belicka, M. Gruntina and others, who have devoted their entire working lives to agricultural science and breeding. In 2006, the agricultural science centre of Stende was transformed into the State Stende Cereal Breeding Institute. Breeding traditions, and cooperation with Latvian farmers, as well as accumulation of knowledge and experience of several generations of scholars is a frame for the existence of the Stende's institute. The most important contribution of Stende's breeders is 65 newly developed varieties of fifteen crop species. Today, the barley variety 'Abava', the winter wheat 'Fredis' and the spring wheat 'Uffo' are well known, not only in Latvia, but also abroad. The achievements of Stende's scientists have gained great appreciation from practicing farmers and agricultural policy makers.
\end{abstract}

\section{INTRODUCTION}

The beginning of the $20^{\text {th }}$ century in Latvia triggered revolutionary changes and social activity. It was a time when Latvian peasants began to establish agricultural societies. The Rìga Central Agricultural Society, formed in the village of Priekuḷi near Cēsis in 1906, became the founder of the Cēsis Agricultural School (1910), Baltic Agricultural Machinery Testing Station (1911), Cēsis Agricultural Testing Station (1913) and Baltic Crop Pest Control Station (1913). Nine agricultural testing institutions launched their activities in Latvia almost at the same time (Anonīms, 1923).

The successful start in agricultural development was interrupted by the First World War in 1914. In 1918, the new government of the Republic of Latvia identified the farm development and growth of agriculture as core priorities (Anonymous, 1923). To facilitate the introduction of modern management techniques and provide easy access to agricultural knowledge throughout Latvia, the government supported the renewal of education in agriculture and restoration of testing institutions, including the establishment of new ones. Agricultural testing institutions had to find solutions to a number of practical agricultural issues, so that Latvian farmers could start using Western scientific knowledge and practical agricultural experience on their farms in the shortest time possible. This article provides information about the establishment of the State Stende Breeding Station, its activities in different time periods, and its achievements from its origin to present.

\section{BREEDING STATION 1922-1940}

In 1920, the government of Latvia launched the agrarian reform, establishing the State Land Fund. In the process of this reform, part of the seized land estates were designated for establishment of new agricultural research institutions. For example, the Stende Manor, owned by the von der Brüggen family, became a state manor in 1920 and later, on 23 April 1922, the Agricultural Department of the Ministry of Agriculture of the Republic of Latvia selected it as the location for setting up the first state breeding station. The favourable geographical location of the manor in the eastern North Kurzeme Uplands, its proximity to railway lines and major roads, as well as the cultivated and flat fields of the estate, were the main prerequisites for transferring the Stende Manor property and inventory, consisting of 540 ha of state-owned land, 45 buildings, livestock and fittings, in the possession of the Stende Seed Production and Breeding Station (Lielmanis, 1928). 


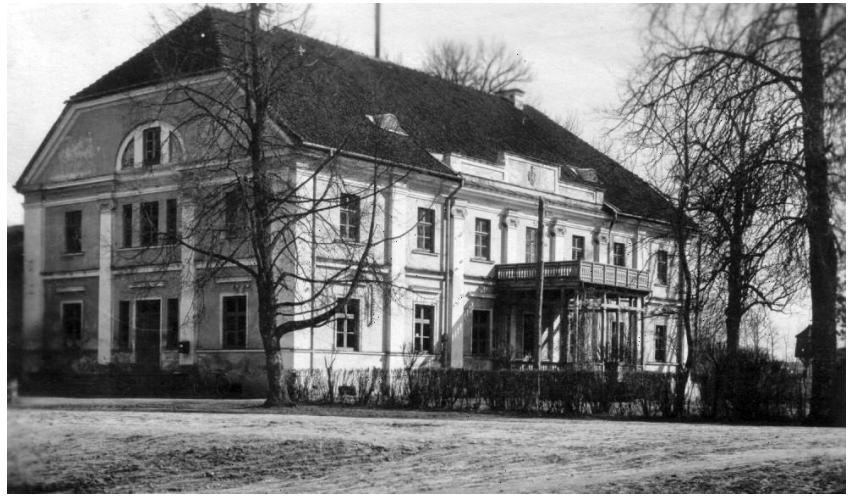

Stende Manor — central building of Stende breeding station (1924).

In spring 1922, A. Jakobsons, the first superintendent (manager) of the breeding station, began reproduction of several barley and oat varieties imported from Germany and Denmark in the fields of Stende, and conducted the first tests under the guidance of the agricultural instructor P. Zarinšs, which involved clover fertilisation with basic ash, potassium salt and different doses of lime. A funding of 1.5 million rubles was allocated to the state station (Lielmanis u.c., 1931). In autumn 1922, the Agricultural Department of the Ministry of Agriculture entrusted the task of superintendent of the breeding station to Jānis Lielmanis, a recent graduate holding a diploma in Agronomy.

The charter of the autonomous state-owned enterprises subordinate to the Agricultural Department, which was approved by the Cabinet in March of 1923, stated that the goal of the Stende Breeding Station was study of foreign crop varieties in Latvian agro-climatic conditions, acclimatisation of these varieties, exploration and improvement of local varieties and cultivation of new varieties (Celma u.c., 2002).

The Stende Breeding Station conducted field trials and produced high-quality seed, and the farm helped to maintain the facilities necessary for research and seed production. Thus, the breeding station developed into a modern model farm of the time, engaged in breeding of pedigree seeds and pedigree livestock.

In summer 1923, a seed sorting station was established at Stende, on instruction from the Agricultural Department. The station was equipped with the then modern Schule seed-sorting machines. The seed testing laboratory also launched its operation. The barn of the manor was fitted with a hot-water seed treatment equipment unique for Latvia - a Dinesen boiler for seed drying in sacks. That year also marked the establishment of the second-class meteorological station and the beginning of construction of the Agrochemical Laboratory at the Stende Breeding Station (Lielmanis, 1931).

In 1923, J. Lielmanis ordered to launch research of seeds imported from abroad in the Stende laboratory, to set up field trials of varieties of vegetable seeds to assess their purity, to begin breeding of rye and comparison of wheat, flax

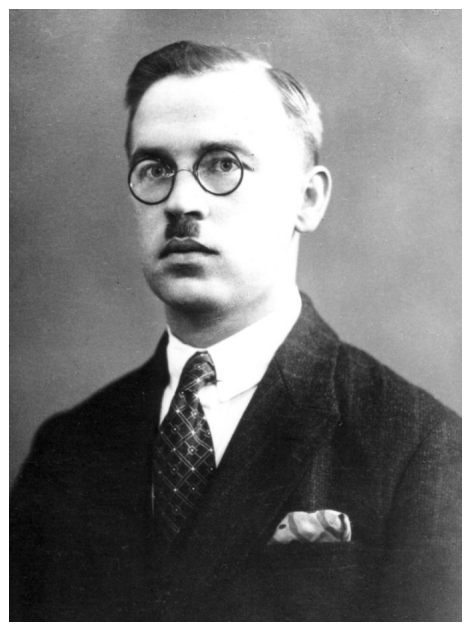

Emīls Bērziņš - breeder of barley, flax, and peas, worked in Stende from 1923 to 1950.

and potato varieties, and to conduct meadow and field fertilisation experiments. J. Lielmanis invited the agronomists Emīls Bērziņš and Jurijs Garbars to work at Stende. In 1925, the Plant Protection Institute Department of the Latvian Central Agricultural Society was established at the Stende Breeding Station, with E. Bērziňš becoming the head of the Department (Lielmanis u.c., 1931).

At the Breeding Station, the agronomist Emīls Bērziņš supervised rye, barley, flax and potato variety testing. Under his guidance, in 1923, the farms collected 33 rye samples, about 100 barley samples, 22 pea seed samples and 74 potato seed samples. Most of the samples were obtained from farms where these seeds had been cultivated for more than ten years (some farmers noted that the seeds had been grown for several generations), yet the origin of the crops or particular variety were unknown. Therefore, most of the samples were named 'Vietējie' (Local), with their description including the name of the farm and the location where they were obtained (Lielmanis u.c., 1947).

In 1924, the selection of rye seeds from the rye samples collected on farms was launched, sowing 255 elite crop seeds. Multistage selection of the most productive rye elite groups resulted in obtaining a variety that was first offered to farmers as 'Stendes oriğinālie' (Original Rye of Stende) in 1929. The selected rye was more productive than both the local unimproved rye $(+14 \%)$ and the Swedish bred Svalöf 'Shield' rye $(+25 \%)$ (Lielmanis, 1935). Testing stations from other Latvian regions (Priekuli, Vidusmuiža, Jaungulbene, Vecauce, etc.) also became involved in comparison of varieties and evaluation of the best selected lines. In addition to variety assessment, the station also carried out testing of rye, by comparing the impact of treated and untreated seeds, seed reproduction, roughness, sowing time and other factors, on the yield of rye (Lielmanis, 1931).

In the early $20^{\text {th }}$ century, four-rowed barley was traditionally grown in Latvia, and local farmers considered it most suitable for brewing. Compared with foreign varieties, the local barley was earlier, yet low-yielding. To improve the yield and quality of the local barley, barley breeding was started at Stende in 1924, and by selection 295 elite plants were chosen from the local barley sample plots. The first 
barley hybrids were obtained in 1925 by hybridisation of four-rowed and two-rowed barley. Along with assessment of barley, researchers at Stende studied the effects of sowing time on barley yield and the optimum density of planting, by comparing the reproduction of the original barley seeds (seeds of varieties imported from overseas) and the seeds bred in local conditions. They demonstrated that the native barley was equivalent in quality to the original foreign seeds, when grown in good conditions, with careful preparation of seed, (Lielmanis u.c., 1947).

In 1923, E. Bērzinšs launched the evaluation of local flaxseed samples and selection of elite plants. The flax varieties were assessed by growth rate, stem length, branching, boll number and other morphological features. The obtained results led E. Bērzinšs to the conclusion that two types of fibre flax were distributed in Latvia - short straw and long straw flax. Most of the local samples were mixtures of short straw and long straw flax. Flax breeding at Stende was based on the cultivation of varieties, by selecting plant forms with the desired characteristics. E. Bērziņš selected two lines of long straw flax, which were named 'Balva' (Prize) and 'Rota' (Adornment) (Lielmanis u.c.,1947). In 1927, the Flax Chemical and Process Technology Laboratory was established at Stende. That year marked the start of testing of flax sowing time, comparison of the production of older and younger generations of seeds, and assessment of the tendency of varieties to degenerate. The studies conducted by E. Bērziňš on the causes of degeneration of Latvian flax varieties in Europe achieved high acclaim in European countries after a series of publications and presentation at the Tenth Congress of Baltic Agronomists (1936). Stende's breeder E. Bērziňš was selected as a winner in the contest announced by the Danish government, which was targeted on finding a solution to this issue (Bērziņš, 1936).

In 1924, Stende began the assessment of local potato seed material, which provided information about the most common varieties on Latvian farms. Most potato samples (about $30 \%$ ) could be identified as the variety 'Silezia', while about $20 \%$ matched with prof. Voltmanis' varieties and about $15 \%$ matched with Merker's ('Emperor') varieties. Field evaluation of the varieties showed that some samples had low productivity. The main reason was poor health status of the seed material, caused by disease (blackleg, seedling rot, etc.). In 1927, the researchers initiated studies on the impact of germinated and non-germinated seed material on potato yield, as well as the effect of the seed origin and production on degeneration of varieties and the possible factors influencing the degeneration. Following the initiative of the Agricultural Department, the researchers set up potato fertiliser experiments, they studied the effect of planting distance and treatment against late blight on yield, and described the spread of potato diseases (Lielmanis u.c., 1931).

Alongside the work on assessment of varieties, the breeder E. Bērzin̄š began the improvement and selection of varieties, as well as cultivation of new varieties from seeds (flower forcing of potato varieties was started already in

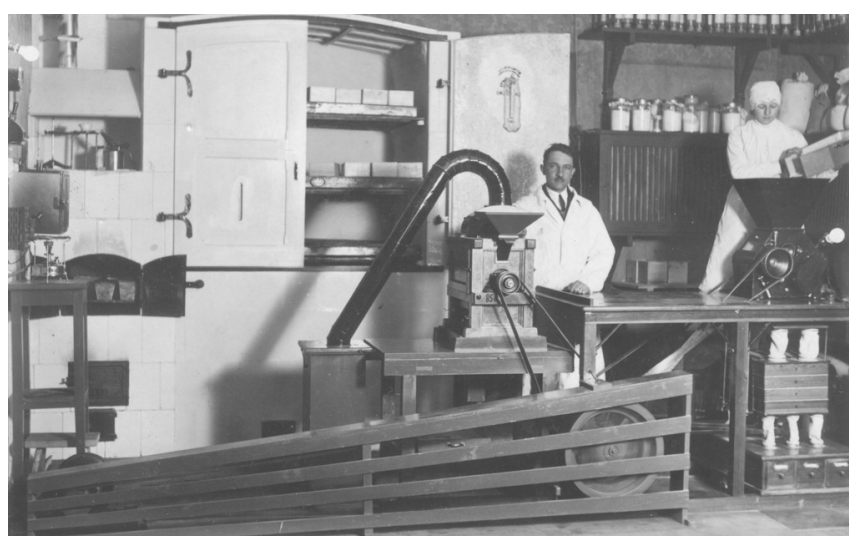

Wheat breeder Jurijs Garbars in Flour and Bread Laboratory of the Stende Breeding Station (1930).

1923). As the process of flower forcing and propagation was very time consuming, the station discontinued potato hybridisation in 1928 and carried on with only evaluation and improvement of varieties (Lielmanis u.c., 1931). In 1937, the breeder Jānis Strazds started work with potatoes at Stende (Celma u.c., 2002).

Jurijs Garbars supervised comparison trials with winter and spring wheat varieties. Targeted winter and spring wheat breeding was launched in 1924, selecting about 110 elite plants from the wheat samples seeded in experimental fields of the station. The main focus in winter wheat breeding was placed on the yield of varieties and local populations, and on winter hardiness, resistance to fungal diseases and lodging, growing season length and grain quality. In 1924, wheat hybridisation was started in order to obtain more productive varieties with a shorter growing season and improved grain quality. In the 1930s, the scientists of Stende engineered two winter wheat varieties, named 'Viestura' and 'Zemgales', as well as a spring wheat variety 'Imanta'. From 1927 to 1929, hybridisation of wheat and rye was conducted at Stende, but these crops died due to adverse weather conditions in 1929 (Lielmanis u.c., 1947).

In 1927, the Stende Breeding Station began grain quality research. They determined the crude protein content and flour output, and in 1928 an oven for bread baking experiments was set up. The trials showed that the content of the local wheat protein was entirely satisfactory for baking bread, and was equivalent to Ukrainian varieties and even surpassed the Western European varieties 'Crievena 104' and 'Teverson'. Overall, the clean wheat lines of the Stende Breeding Station had very good bread-baking characteristics (Lielmanis u.c., 1931).

J. Garbars was also in charge of sugar beet trials, which began at Stende in 1927 on request of the first Latvian sugar refinery in Jelgava. The goal of the trials was to identify sugar beet varieties suitable for Latvian conditions. These trials continued at Stende until 1933, when they were transferred to the newly established Mežotne Breeding and Research Station (Lielmanis, u.c., 1947). 
J. Lielmanis, superintendent of the station, coordinated evaluation and selection of oat, pea and clover varieties. In 1930, Nikolajs Konrāds started work at Stende as assistant to J. Lielmanis and later became an outstanding oat breeder (Anonīms, 2004). The first oat samples (about 50) were collected from farms in 1922-1923. In 1923, the station conducted the comparison of 127 local and foreign varieties of oat in order to determine their yield, growing season length and resistance to oat rust and lodging. J. Lielmanis classified the local oat samples into four groups: small early oats, local single-side oats, local large-kernelled oats and local small-kernelled middle-late oat. The breeder selected the best lines from the local oat and obtained a relatively productive, fast-growing line of oat No. 30, which was reproduced and offered to farmers as oat variety 'Stendes mazās agrās' (Small Early Oat of Stende) starting from 1930. The yield of this variety was equivalent to the yield of 'Victory' oat ('Segerhavre') of Svalöf, and outperformed the Swedish variety in terms of growth rate, and maintained good productivity performance also in late sowing periods. Along with evaluation of varieties, the researchers of Stende determined the optimum period for sowing oat and effect of sowing period and seeding density on grain quality. They also explored tillering of various oats, effect of fertilisation on yield, determined the crude protein content in different oat varieties, and described the spread of oat rust in planted oat varieties (Lielmanis u.c., 1947).

Trials with local and foreign varieties of pea started in 1925 , when 14 varieties were sown. Only two samples of seeds were collected as local pea in Latvia: local brown-grey pea of Kurzeme and big brown-grey early pea of Vidzeme ('Retrija'). In 1929, research of pea/oat mixtures was launched at Stende (Lielmanis, 1939). The study of field bean varieties began in 1931, and lupine trials started in 1935. In 1938, Arvīds Sniedze, a legume breeder, joined the team at Stende and became assistant to Nikolajs Konrāds. Both breeders initiated experiments with lupine, using rhizobia, conducted lupine hybridisation selected elite plants, and evaluated and selected the local spring vetch varieties. Trials with field bean, brown pea (field pea) and lupine seeds involved seed vernalisation at different temperatures and pre-sowing seed soaking (Lielmanis u.c.,1947).

In 1925, J. Lielmanis initiated and supervised assessment tests on productivity of various local populations of red clover with five early and 35 late clover seed samples at Stende. At that time, mostly late clover was cultivated in Latvia, which yielded only one harvest per season, but had a better survival rate through winter (Lielmanis u.c., 1947).

In 1936, the Ministry of Agriculture of the Republic of Latvia adopted a decision on specialisation of breeding stations in breeding of particular species. The Stende Breeding Station was instructed to continue with breeding of winter rye, winter and spring wheat, two-rowed barley, oat, flax and red clover, whereas the breeding of four-rowed barley and potato was transferred to the Priekul,i Breeding Station. Stende was instructed to launch the breeding of grasses rough bluegrass, alsike clover and hemp, as well as propa- gation of export market potato varieties, by selecting virus-free shrubs. The Mežotne Breeding Station was engaged in the breeding of early red clover and meadow grass. In 1936, the grasses breeder Anatols Meiers started work at Stende. During the Second World War, A. Meiers coordinated the activities of the experimental farm of the Stende Breeding Station (Holms, 1992).

Table 1

FIELD CROP VARIETIES DEVELOPED IN THE STATE STENDES BREEDING STATION, 1922-1945

\begin{tabular}{|c|c|c|}
\hline Species & $\begin{array}{c}\text { Variety (year of } \\
\text { development) }\end{array}$ & Breeders \\
\hline Winter rye & Stendes (1929) & E. Bērziņš \\
\hline Winter wheat & $\begin{array}{l}\text { Viestura I (1930); Zemgale } \\
\text { (1930); Viestura II (1937); } \\
\text { Kursa (1940) }\end{array}$ & J. Garbars, E. Bērziņ̧̌̌ \\
\hline Spring wheat & Imanta (1933) & J. Garbars \\
\hline Oat & $\begin{array}{l}\text { Stendes mazās agrās } \\
\text { (1930); Dzintara } \\
\text { vienpusauzas (1932); Līgo } \\
\text { (1936); Pērḷu (1940) }\end{array}$ & J. Lielmanis, N. Konrāds \\
\hline Barley & Dzintara (1930) & E. Bērziņš \\
\hline Long straw flax & $\begin{array}{l}\text { Balva (1930); Rota (1930); } \\
\text { Rota II (1938) }\end{array}$ & E. Bērziņš \\
\hline Read clover & Stendes vēlais (1938) & J. Lielmanis \\
\hline
\end{tabular}

The Ministry of Agriculture instructed the State Stende Breeding Station to offer high-quality seeds to farmers. In 1930, seeds of five varieties were prepared for sale at the farm of the station, while in 1932 the number of crop seed varieties increased to 17 . These included the new varieties developed at Stende (such as 'Stendes oriǵinālie' rye, 'Viestura' and 'Zemgales' winter wheat, 'Dzintara' four-rowed barley, 'Stendes mazās agrās' oat, 'Dzintara' single-side oat and 'Balva' and 'Rota' flax) and also eight varieties of potato, barley, oat and pea from Svalöf and other European breeding companies. In 1935, the jointstock company Latvian Central Seed Exports (L.C.S.E.) was founded. This enterprise took over the sale of seeds of different varieties in Latvia and abroad. The Stende Breeding Station used the services of this company to sell a part of the prepared seeds. To raise awareness of good farming practices, the scientists of the breeding station helped organise and monitor model farms in the district. Cooperation with the local farms was very active. As a result, seven farms of Talsi District received awards of the Latvian Agricultural Chamber in 1936 (Celma u.c., 2002).

\section{TIME OF CHANGE, 1940-1945}

In 1940, Latvia was affected by political turmoil, which was followed by the dramatic developments of the Second World War. In summer 1940, Latvia was incorporated into the Soviet Union. Although most scientists of Stende continued their work, these changes altered the operations of the station. In autumn 1940, J. Lielmanis, the superintendent of the station, moved to live and work in Rīga, and the 
breeder Emīls Bērziņš was appointed as the acting superintendent until the end of 1943 (Anonīms, 2007). During the German occupation (1941-1945), the Stende Breeding Station was renamed as the Stende Seed Nursery (Saatzuchtstation Stende). The scientists continued comparative trials with varieties of barley, oat, rye, pea, field bean, vetch, hemp, poppies, mustard, buckwheat, forage beet, kale, forage turnip, carrots and other crops. In May 1941, Stende initiated trials with the rubber-producing plant Taraxacum kok-saghyz. The collection of varieties was extended with new samples from Russia and Germany (Celma u.c., 2002). In spring 1941, the wheat breeder Jurijs Garbars and his assistants moved to the newly established Pêterlauki Research Station and later to the Mežotne Breeding and Research Station, taking with them most of the wheat breeding material created at Stende. During the period of the Second World War, J. Garbars together with the Russian agronomist Evdokia Nikolaenko supervised the reproduction and conservation of Nikolai Vavilov's seed collection, which was moved from Leningrad to Latvia during the war (Kalmanis, 2000).

In 1944, the buildings of the Stende Breeding Station were handed over to the German army, and a military hospital were set up in Stende Manor. The employees of the station Nikolajs Konrāds, Emīls Bērziņš and Jānis Škipsna moved the main documents related to research and breeding, as well as a part of the research library, to their apartments (Celma u.c., 2002; Anonīms, 2004). The scientists of Stende managed to save only some of the breeding nursery material and crop collections.

At the end of 1944, the Soviet regime was re-established in the territory of Latvia, introducing the laws of the Russian Soviet Federated Socialist Republic. In December of that year the Council of People's Commissars of the Latvian Soviet Socialist Republic (LSSR) decided to found an institution of national subordination: the Stende Breeding and Research Station of the Ministry of Agriculture of the LSSR. However, in the last months of 1945, the station was incorporated in the system of the USSR state breeding stations. In May 1945, Jānis Lielmanis was appointed as the acting director of the station. 663 ha of land, including 251 ha of arable land and 220 ha of grassland, as well as 40 horses, 49 cows, 24 pigs and 24 sheep were placed at the disposal of the station (Celma u.c., 2002). The scientists of the breeding station made efforts to revive the breeding work, which had fallen into decline during the war years.

\section{SOVIET ERA 1946-1957}

The 1940s and the 1950s were a very difficult phase in operation of the breeding station, which was markedly different from the previously established order. At the beginning of 1946, the USSR People's Commissariat of Agriculture appointed Ivans Liepa, former director of the North Ossetia Breeding Station, as the director of the Stende Breeding and Research Station. The research work at the station was car-

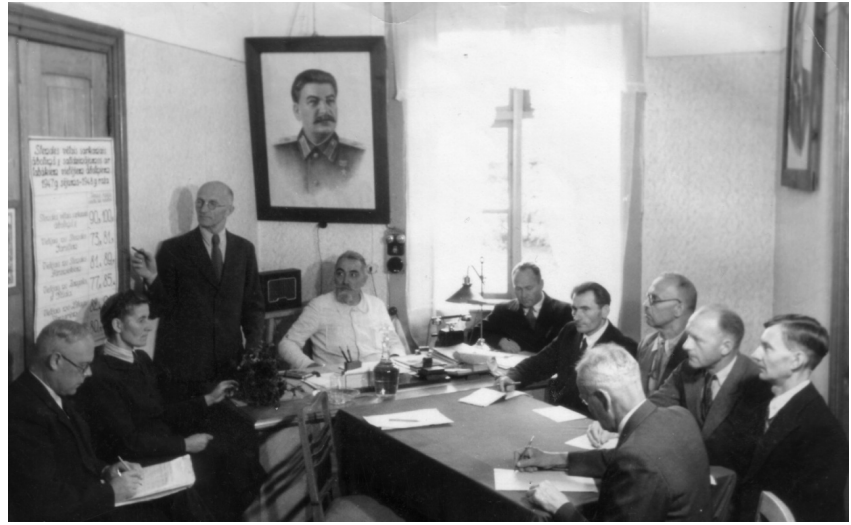

Meeting of the Research Council in the Stende Breeding and Experimental Station (1948), from the left: oat breeder N. Konrāds, barley breeder Z. Strumpe, head of the Breeding Department J. Liemanis, Director J. Liepa, Deputy Director K. Zagika, head of the Agrochemistry Laboratory P. Rusmanis, pea and wheat breeder E. Bērziņš, head of the Growing Technology Department E. Gailitis, head of the Plant Protection Laboratory J. Škipsna, potato breeder J. Strazds.

ried out by the Breeding Department (managed by Emīls Bērziņš), the Growing Technologies Department (managed by Ëriks Gailitis) and the Phytopathology and Entomology Department (managed by Jānis Škipsna). In 1946, a new organisational structure, the Research Council, was launched. The council was composed of the breeding station's administration, scientific representatives and officials from the Ministry of Agriculture and other state agricultural institutions. The Council was given a mandate to approve the yearly plans for the station's operations and methodological research plans, and to monitor their implementation and compliance with the decisions of the Central Committee of the All-Union Communist (Bolshevik) Party (Celma u.c., 2002).

Reforms affecting the administration of the station continued for years to come. In 1950, the LSSR Office for Agriculture proposed to reorganise the breeding station into an integrated agricultural testing station composed of the Breeding Department, the Growing Technologies Department, the Cattle Breeding Department together with Horse Breeding, Feeding and Feed Supply Groups and the Economic and Agriculture Organization Department, as well as special research departments: the Taraxacum Kok-Saghyz Department and the Scientific Knowledge Implementation Department (Celma u.c., 2002).

During that period, a number of scientists from Russia started work at the station. The agronomist and economist Zelma Strumpe, who had studied in Omsk and worked in the Soviet collective farm system, began barley and spring wheat breeding in 1946 (Kalmanis, 2001). The wheat breeder Raisa Kude and the grass breeder and seed production specialist Antonina Kaudze joined the team of the Research Division of the breeding station in 1950. The new employees were qualified breeders and held diplomas in breeding from the Leningrad Agricultural Academy (Kalmanis, 2003). 
The scientists of Stende had to follow political or pseudoscientific instructions. For example, they had to demonstrate that they supported and in their work followed the theory of the Soviet academician Timofey Lysenko, who rejected traditional breeding methods and recognised changes caused by various external factors as hereditary changes in species. This led to research on the transformation of spring wheat into winter wheat. During that time, J. Lielmanis was released from his position as the deputy director, as he was proclaimed to be a "antiscientific nationalist". In 1948, orders were received from Moscow regarding the implementation of the grasses system. Stende, among other stations, had to expand perennial grass cropping and studies with grass species. In the autumn of that year, the scientists of Stende received a public condemnation from the USSR Minister for Agriculture for not introducing a full grass crop-growing system at the station (Celma u.c., 2002). In 1950, the experienced breeder E. Bērziņš was released from his job for expressing his "non-Soviet" scientific view in publications (Anonīms, 2007).

Although the scientists were reprimanded by politicians in different levels for using too little of the "front-rank scientific Soviet methodologies", this did not reduce the interest of farmers in the varieties created at Stende. The breeders continued their work and in 1949-1950 filed nine new varieties of various crops for registration.

Table 2

FIELD CROP VARIETIES DEVELOPED IN THE STENDE BREEDING AND RESEARCH STATION, 1946-1957

\begin{tabular}{|c|c|c|}
\hline Species & Variety (year of development) & Breeders \\
\hline Winter rye & Stendes II (1949) & E. Bērziņš, E. Eglīte \\
\hline Winter wheat & $\begin{array}{l}\text { Milturum } 5 \text { (1949); Kurzeme } \\
\text { (1956) }\end{array}$ & $\begin{array}{l}\text { J. Garbars, E. Bērzin̄š, } \\
\text { R. Kude }\end{array}$ \\
\hline Spring wheat & $\begin{array}{l}\text { Stendes } 5 \text { (1951); Stende } \\
\text { (1957) }\end{array}$ & $\begin{array}{l}\text { J. Garbars, K. Zagika, } \\
\overline{\text { E}} . \text { Krēsliņšs }\end{array}$ \\
\hline Oat & $\begin{array}{l}\text { Stendes (1949); Mutica } 7281 \\
\text { (1953); Mičurinietis (1954) }\end{array}$ & $\begin{array}{l}\text { J. Lielmanis, } \\
\text { N. Konrāds; K. Zagika }\end{array}$ \\
\hline Barley & Kombainieris (1950) & Z. Strumpe, J. Garbars \\
\hline Peas & $\begin{array}{l}\text { Pionieris (1949); Stendes Hero } \\
\text { (1949); Stendes pelušķi (1950) }\end{array}$ & $\begin{array}{l}\text { V. Steimārs, A. Sniedze, } \\
\text { K. Roze, J. Lielmanis }\end{array}$ \\
\hline Spring vetch & Stendes 653 & $\begin{array}{l}\text { J. Liemanis, K. Roze, } \\
\text { A. Sniedze }\end{array}$ \\
\hline Read clover & Stendes vēlais II (1949) & J. Lielmanis, N. Konrāds \\
\hline Potatoes & Stendes baltie (1956) & $\begin{array}{l}\text { J. Strazds, A. Tumova, } \\
\text { A. Dance }\end{array}$ \\
\hline
\end{tabular}

In addition to breeding work, another high-priority topic of research was the establishment of field crop rotation systems. The breeding station set up a permanent crop rotation study area with nine-field crop rotation systems and identified the grasses/legumes plant mixture, mechanical and chemical techniques of weed control and optimum cereal seeding rates, which were most suitable for different crop rotations. Throughout the Soviet Union, it was recommended to cultivate branched wheat and Taraxacum kok-saghyz. The scientists of Stende also began to study these species in field trials, and in 1950 the Taraxacum
Kok-Saghyz Department, managed by the breeder Ëriks Gailitis, initiated breeding of this crop. In 1953, it was established that branched wheat cultivation and breeding of the Taraxacum kok-saghyz had not been successful in Latvian conditions.

In the mid-1950s, the Breeding Department, managed by J. Lielmanis, started breeding of forage cabbage, winter vetch and lupine, in addition to breeding of cereals, pea, meadow fescue, timothy and red clover. The Growing Technologies Department extended the permanent crop rotation study area to include investigation of tillage (under the guidance of Stanislavs Čudars), as well as evaluated cereal/legume mixes, peat composting techniques, application rates of different fertilisers and fertiliser application techniques for cereal, potato and other crop species (under the guidance of Aina Stāmere and Vitauts Osmanis). The Forage Production Department highlighted research on the use of various crops for silage production, improvement of forage and sugar beet productivity, maize cultivation and establishment of cultivated meadows and pastures (under the guidance of the scientists Ëriks Gailītis, Ēvalds Krēsliņ̌ and Biruta Paulina). The Plant Protection Laboratory, managed by Jānis Škipsna, conducted research on the agents of snow mold, clover wilt and cereal root rot, and their containment. The Agrochemical Laboratory carried out biochemical testing of plant and soil, not only for the purpose of scientific research, but on demand of the Kurzeme Region's collective farms (Celma u.c., 2002).

The state authorities instructed the scientists to provide agronomical and organisational assistance to the newly established kolkhozes (collective farms). According to the station's scientific report of 1950, researchers made 147 visits to the collective farms, delivered 127 lectures to farmers, and conducted trials of varieties at 52 farms on 90 hectares of land (Celma u.c., 2002). Also, the scientists educated farmers by providing guidance in published material (books, pamphlets and periodicals).

\section{SOVIET ERA 1957-1970}

In 1956, the Ministry of Agriculture of Latvian SSR incorporated, as its departments, all breeding and testing stations into the Latvian Scientific Research Institute of Agriculture. In 1959, the Ministry appointed Jānis Mendiāns as the director of the station, and in 1965 the position of the director was given to Arvīds Plikšs. The Lejaskurzeme Breeding and Research Station became the parent institution of a subsidiary of the Stende Breeding and Research Station. Lejaskurzeme was engaged in forage crop breeding, seed production and agricultural engineering research. As democratisation of the Soviet management system progressed, the station introduced competitive elections of the scientific staff and certification of the employees and managers at all levels (Celma u.c., 2002).

The Research Division underwent yet another change. The breeding operations were organised into two departments, 


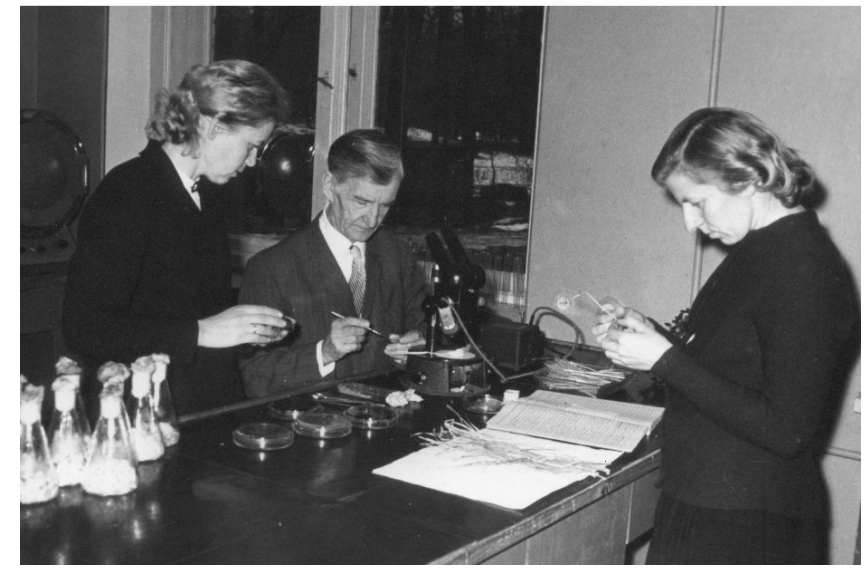

Plant Protection Laboratory, from the left: candidate of science I. Belicka, head of the laboratory J. Škipsna, scientific co-worker Dz. Metuzāle (1970).

the Cereal and Legume Breeding Department and the Forage Crop Breeding Department, with further division into the relevant working groups for breeding of winter wheat/ winter vetch, winter rye/oat, barley/pea, spring wheat/field bean, red and alsike clover, field pea/timothy, wild perennial legumes plants/ Taraxacum kok-saghyz, perennial lupine, sweet clover and potato. The Growing Technologies Department was instructed to set up a tillage and crop rotation research group, a potato fertilisation and green manure research group, and an organic manure, mineral fertiliser and cereal/legume mixture research group. The Forage Production Department established a group for hay meadow fertilisation and management, and green feed crop mixture and grass seed production, and a group for cultivated pasture and lupine seed production. The Plant Protection Laboratory and the Agrochemical Laboratory continued their activities. During that period, Stende became a venue for the most extensive and varied field trials in the history of the station. The clover breeder Irma Celma, the researcher of meadows and pastures Rasma Pētersone, the growing technologies researcher Ziedonis Sìmansons and other new scientists joined the team of Stende (Celma u.c., 2002).

In the early 1960s, the station introduced vegetative propagation of herbaceous plants from cuttings and the use of mutagenesis in cereal breeding. The Plant Protection Laboratory managed by J. Škipsna was the first in Latvia to use the serological method to detect potato viruses. Moreover, it

Table 3

FIELD CROP VARIETIES DEVELOPED IN THE STENDE BREEDING AND RESEARCH STATION, 1958-1970

\begin{tabular}{lll}
\hline \multicolumn{1}{c|}{ Species } & Variety (year of development) & \multicolumn{1}{c}{ Breeders } \\
\hline Oat & $\begin{array}{l}\text { Stendes dzeltenās (1959); } \\
\text { Stendes vēlās (1960) }\end{array}$ & N. Konrāds \\
Barley & Kombainieris II (1968) & Z. Strumpe, G. Timule \\
$\begin{array}{l}\text { Winter } \\
\text { vetch }\end{array}$ & Stendes 24 (1961) & J. Liemanis \\
Read clover & Stendes agrais (1960) & J. Lielmanis, I. Celma \\
Timothy & Stendes vēlais (1962) & A. Kaudze
\end{tabular}

started using an artificial infection background to assessing the health of seed material. The Growing Technologies Department carried out experiments with spraying fields using aircraft. Stende conducted a wide range of corn studies and began breeding of corn, sweet clover and field bean (Anonymous, 1960). In 1966, the station stopped breeding of food and feed barley and continued selection of barley varieties for brewing only (Holms, 1992).

During that period, in accordance with procedures laid down in the USSR, the scientists of the station defended their Candidate of Sciences theses (which after 1990 were equated to promotion theses for obtaining the Doctoral degree). The topic of I. Celma's research was rye yield and quality, in relation to on sowing time and time of nitrogen fertiliser application (1962). E. Krēsliņš wrote his thesis on tilled crop cultivation in the Kurzeme area (1969). The Soviet power did not accept the scientific degree awarded to Jānis Lielmanis in 1937, and the scientist had to reaffirm his knowledge by defending the Candidate of Sciences thesis, on Cultivation of Red Clover 'Stendes vēlais II' (Late Clover of Stende II) (1957) (Celma u.c., 2002). The scientists of Stende were engaged in cooperation with a number of agricultural science centres of Russia, Belarus, Lithuania, and Estonia. In 1961, the station established the scientific knowledge and best practice extension service, with the aim to provide training for farmers, and held courses for seed production specialists.

\section{SOVIET ERA 1970-1990}

In 1970, the Ministry of Agriculture appointed Mārtiņš Belickis as the director of the Stende Breeding and Research Station. The breeding station, being the model farm of Talsi District, managed 1958 ha of land. In 1977, the collective farm "Libagi" was integrated into the station, as a result of the government's mandate to establish large farms, and the total area of land increased to 7352 ha (Belickis, 1975).

In 1971, Ēvalds Metuzāls, the head of the Growing Technologies Department, was appointed as the deputy director for research. The Research Division of the station was composed of the Breeding Department with the Plant Protection Laboratory, the Growing Technologies Department with the Agrochemical Laboratory and the Seed Production Department. In the 1970s and 1980s, a number of new buildings were constructed at the breeding station. The experimental station acquired a large scale farm for dairy cattle, a potato cellar and a seed production unit, as well as engineering workshops, multiunit residential houses for the staff and an electric heating system. The Research Division installed accelerated plant growth chambers, purchased the first compact combine harvester "Sampo" and made plans for construction of a new laboratory building and greenhouses (Celma u.c., 2002).

During the period of dynamic changes, a new generation of scientists joined the team at Stende. In 1970, Ina Belicka, 


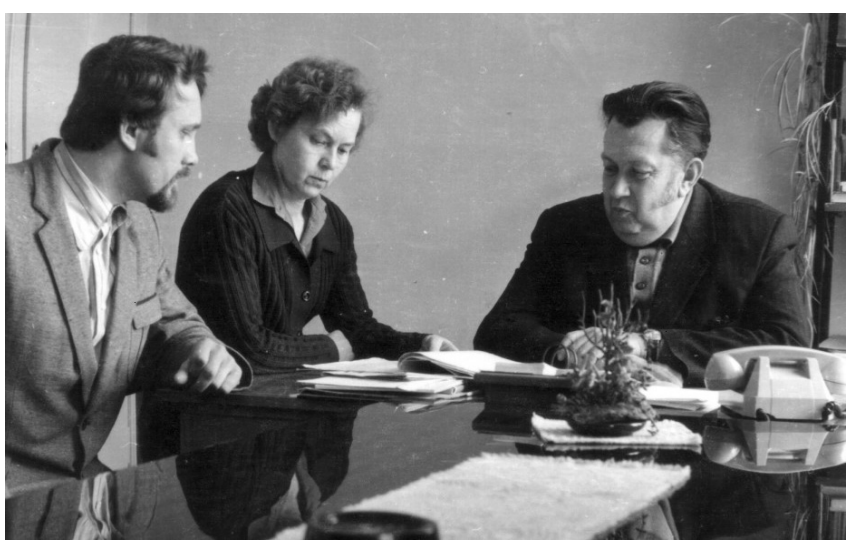

Researcher M. Krotovs, barley breeder I. Belicka and Deputy Director E. Metuzāls (1982).

cand. sc. (Biology) became the head of the Plant Protection Laboratory. After the laboratory was closed in 1977, she coordinated the barley breeding operations. During that time, future scientists Vija Strazdiņa (1970), Velta Vīksne (1973), Sofija Kalininina (1976) and Miervaldis Krotovs (1978) began work at the station. In 1978, Pēteris Bulbiks, cand. sc. (Agriculture) was appointed as the manager of the oat breeding operations. The new scientists pursued extramural postgraduate studies at the All-Union Institute of Plant Cultivation in Leningrad, where they defended their Candidate of Sciences theses. Vitauts Osmanis wrote his thesis on the effects of means of nitrogen fertilisation and techniques on crop yield and quality (1972), Rasma Pētersone explored the effects of fertilisation, grass cover restoration and intensive use on grassland productivity (1975), while Sofija Kalininina's thesis topic was barley resistance to lodging (1989) (Celma u.c., 2002).

The breeders offered nine new cereal varieties to producers, including the barley variety 'Abava', which was created by the breeder Genovefa Timule, the head of the Breeding Department Raisa Kude and the director Mārtiņš Belickis. The merits of the scientists were honoured by the LSSR State Award (1982). This variety was widely cultivated in several regions of the USSR. The oat variety 'Stendes dzeltenās' (Yellow Oats of Stende) was grown in Russia and Kyrgyzstan, as well as in Poland and Germany (Celma u.c., 2002).

The Growing Technologies Department continued research on tillage practices (E. Metuzāls), carried out trials in the permanent crop rotation study area, increased the share of tilled crops (S. Čudars), assessed the effectiveness of the first anti-lodging agents and systemically active pickle of

Table 4

FIELD CROP VARIETIES DEVELOPED IN THE STENDE BREEDING AND RESEARCH STATION, 1971-1990

\begin{tabular}{llll}
\hline \multicolumn{1}{c|}{ Species } & Variety (year of development) & \multicolumn{1}{c}{ Breeders } \\
\hline \multirow{2}{*}{ Oat } & Santa (1978); Māra (1985); & N. Konrāds, P. Bulbiks, \\
& Līva (1986) & M. Gruntiṇa \\
Barley & Stende (1971); Abava (1976); & Z. Strumpe, G. Timule, \\
& Imula (1985) & I. Belicka, S. Kaḷinina \\
\multirow{2}{*}{ Winter wheat } & Raive (1980); Stende (1981); & R. Kude, V. Strazdiṇa, \\
& Krista (1988) & M. Ceraukste
\end{tabular}

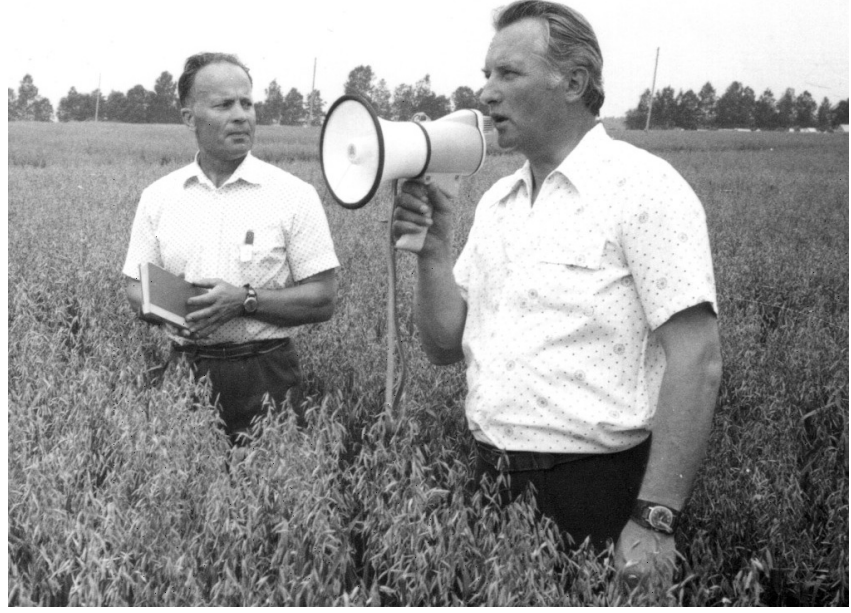

Oat breeder P. Bulbiks and Director of the Stende Breeding and Research Station M. Belickis (1986).

new type (A. Stāmere), evaluated effects of fertilisation on seeding of red clover cover crops (I. Celma) and developed management techniques for cultivated pastures and meadows (R. Pētersone). The station began research on cultivation of lucerne, rape, oil radish, white mustard and forage galega. The Seed Production Department provided elite and super elite seeds of ten crop varieties, not only for farms in Latvia, but also in different regions of the USSR (Celma u.c., 2002).

Overall, during the period between 1970 and 1990, the Stende Breeding and Research Station made extensive investments in the development of the experimental farm and experienced a significant increase in production volume. The station was financially secure and invested heavily in the growth of its infrastructure.

\section{TIME OF CHANGE 1990-1997}

After the political changes that occurred in the USSR in 1990 and the subsequent declaration of Latvia's independence, the activities of the breeding station underwent significant transformation. Former owners reclaimed a large part of the land operated by the station for farming. In April 1991, the station had only 870 hectares of land at its disposal. The demand for seeds slowed down significantly, whereas energy prices increased sharply. The economic situation of the farm became complicated. During that period, the breeding station was directed by the former agronomist Guntis Berkis, and the Research Division was managed by Miervaldis Krotovs, the head of the Growing Technologies Department (Celma u.c., 2002).

The spring of 1991 marked the completion of construction work in the new laboratory building and the greenhouses. The researchers of Stende started to set up the grain technology and quality laboratory, the biotechnology laboratory and the plant protection laboratory. The initiative breeders helped restore the spring wheat breeding operations at 
Stende in 1991, which were stopped in Latvia in 1968 (Strazdina, 2010).

In 1992, Latvia's academic education system launched new Master's programmes. The young scientists of the breeding station, Ilze Priekule, Gints Lanka, Sanita Zute and Solveiga Malecka, carried out their research for obtaining Master's degrees in cereal breeding under the guidance of Ina Belicka, an experienced breeder and professor at the Latvian University of Agriculture. The scientists of Stende established new contacts in the U.S., Canada, Sweden, Finland and other countries in Europe. New opportunities opened up for participation in a wide variety of international scientific events, study visits and international projects. The year 1993 was the start of cooperation with the U.S. Department of Agriculture. From 1995 to 1997, V. Strazdina, I. Priekule and S. Kalinina improved their knowledge at the Oregon State University within the Cochran Fellowship Programme. Also, young scientists participated in courses for PhD students held by the Nordic countries (Celma u.c., 2002).

The breeders prepared eight new cereal varieties for registration. To maintain the genetic resources of Latvia's plants, it was decided to start keeping records and collection of crop varieties created in Latvia, for establishment of the Latvian Crop Gene Bank. In 1997, the varieties developed at the breeding station and the most valuable breeding material were handed over for this purpose (Strazdina, 2010).

Table 5

FIELD CROP VARIETIES DEVELOPED IN THE STENDE BREEDING AND RESEARCH STATION, 1991-1997

\begin{tabular}{lll}
\hline \multicolumn{1}{c|}{ Species } & Variety (year of development) & \multicolumn{1}{c}{ Breeders } \\
\hline Oat & Laima (1991); Arta (1993) & P. Buḷbiks, M. Gruntiņa \\
Barley & Rasa (1991); Sencis (1994); & S. Kaḷiņina G. Timule, \\
& Ansis (1995) & I. Belicka, A. Cela \\
Winter & Sakta (1993); Banga (1995); & V. Strazdiña, \\
wheat & Elva (1997) & M. Ceraukste \\
Read clover & Dižstende (1994) & I. Celma
\end{tabular}

In 1995, the breeding station arranged the first field trials requested by private companies. The Latvian Rural Advisory and Training Centre requested demonstrations of field trials at Stende aimed at training farmers, which was financed from PHARE Programme funds.

The economic situation in the country and, therefore, at the breeding station became increasingly difficult. The large scale agricultural production was uneconomical, and at the end of 1996, the Ministry of Agriculture initiated reorganisation of the Stende Breeding and Research Station, by offering the experimental farm of the station for privatisation. To ensure continuation of breeding operations and field trials, the state allotted 120 hectares of land and the main buildings of research infrastructure. As a result, the non-profit scientific state organization — the State Stende Breeding Station - began its operations under the auspices of the Ministry of Agriculture of the Republic of Latvia in March of 1997 (Celma u.c., 2002).

\section{STENDE BREEDING STATION 1997-2006}

The Research Council of the State Stende Breeding Station appointed Miervaldis Krotovs, the former deputy director for research, as the director of the station. The following working groups functioned as the departments of the station in 1997: oat breeding (Sanita Zute), barley breeding (Sofija Kalinina), winter wheat breeding (Vija Strazdina), spring wheat breeding (Gints Lanka), cereal growing technology (Miervaldis Krotovs), grassland agricultural engineering (Irma Celma), primary potato seed production (Lidija Vojevoda), laboratory of cereal pathology (Ilze Priekule), grain technology and quality laboratory (Vita Kuzma) and agrochemical laboratory (Vilnis Krikis). Due to the lack of funding, the laboratory of cereal pathology had to be closed down in 1999, and evaluation of breeding material became the task of the breeders. In 2000, the grain technology and quality laboratory and the agrochemical laboratory were merged into the grain quality and agrochemical laboratory (Viktorija Miglāne). From 1997 to 2006, the research infrastructure of the station was used by four young scientists in preparation of their Master's degree theses. The oat breeder Sanita Zute defended her Doctoral degree promotion thesis on selection criteria in oat section (2002) (Celma u.c., 2002).

The scientists of Stende participated in three Latvian Council of Science research programmes of national importance, in which they conducted the breeding of cereal varieties suitable for Latvian conditions, investigated cereal yields and quality and explored the possibilities for soil fertility improvement. In addition to the research programmes, the station entered into cooperation contracts with various partners for exchange and study of breeding material and evaluation of effectiveness of fertilisers and plant protection products.

A number of students from the Latvia University of Agriculture and different agricultural schools underwent their work placement at Stende. After collapse of the collective farming system, many owner-operated farms were established. The agricultural extension service expanded its activities and invited the scientists of the breeding station to deliver lectures aimed at raising the farmer awareness of agronomic issues. To share the results of research and promote crop varieties, the station initiated annual seminars, Farming Days at Stende, in 1996 (Celma u.c., 2002).

In 1997, the Ministry of Agriculture provided funding for restoration of the field research facilities of the station, by providing financing for aq compact combine harvesters $H E G E$, cartridge seeders, grain threshers and other equipment and by constructing a warehouse and a drying unit for primary cereal seed production. The demand for seeds of Stende's varieties increased again. Therefore, in 1999 the station set up a separate seed production unit aimed at prep- 
aration of the pre-basic seeds of the available varieties. From 2000 to 2003, the breeding station implemented the state investment project for modernisation of the seed production facilities. This project involved the construction of a new seed warehouse with installation of a seed dressing line and a modern potato cellar with automatic climate control, as well as purchase of other units for seed production needs (Celma u.c., 2002).

During that period, the breeders filed five new varieties for registration, developed cooperation with the Laboratory of Plant Genetics, Institute of Biology, University of Latvia with the view of practical application of original biotechnology methods in breeding, and obtained the first wheat and barley plants from pollen crops and doubled haploids in partnership with Professor Isaak Rashal (İzaks Rašals) and Dr. Dace Grauda (Strazdina, 2010).

Table 6

FIELD CROP VARIETIES DEVELOPED IN THE STATE STENDE BREEDING STATION, 1998-2012

\begin{tabular}{|c|c|c|}
\hline Species & Variety (year of development) & Breeders \\
\hline Oat & Stendes Darta (2001) & $\begin{array}{l}\text { M. Gruntiņa, S. Zute, } \\
\text { P. Buḷbiks }\end{array}$ \\
\hline Barley & $\begin{array}{l}\text { Druvis (1999); Kristaps } \\
\text { (2002); Austris (2006); } \\
\text { Kornelia (2012) }\end{array}$ & $\begin{array}{l}\text { S. Kalininina, V. Vīksne, } \\
\text { A. Nīcgale, M. Bleidere }\end{array}$ \\
\hline Winter wheat & $\begin{array}{l}\text { Hugo (1999); Banga S (2002), } \\
\text { Fredis (2005), Talsis (2009), } \\
\text { Edvins (2010), }\end{array}$ & V. Strazdina, M. Ceraukste \\
\hline Spring wheat & Uffo (2005); Robijs (2008.) & $\begin{array}{l}\text { V. Strazdina, G. Lanka, } \\
\text { M. Ceraukste, M. Bleidere }\end{array}$ \\
\hline
\end{tabular}

In 2001, the station started development of a new crop rotation system for research in organic farming. Professor Ina Belicka returned to work at Stende and coordinated the implementation of the ENVIRFOOD EU $6^{\text {th }}$ Framework project on breeding of crop varieties for organic production, which was conducted in 2004-2005. The final workshop of the project was attended by scientists and breeders from six European countries.

\section{STATE STENDE CEREAL BREEDING INSTITUTE: FROM 2006 TO THE PRESENT}

In 2006, following a change in legislation of Latvia, research institutions underwent yet another reorganisation, now as a state agency. In January 2007, the state agencies were converted to secondary public persons. The State Stende Breeding Station, among others, had to change its legal status and become a secondary public person: the State Stende Cereal Breeding Institute. In these times of change, the director of the Stende Breeding Station and later of the Institute was Sanita Zute (2002-2012), and the Research Council was chaired by Professor Ina Belicka (2003-2009). The Institute operated 205 ha of state-owned land and employed around 50 people, including 15 scientists, researchers and their assistants, as well as six agronomists.
FIELD CROP VARIETIES OF THE STATE STENDE CEREAL BREEDING INSTITUTION, 2006-2012

\begin{tabular}{l|l|l}
\hline \multicolumn{1}{c|}{ Species } & \multicolumn{1}{c}{$\begin{array}{c}\text { Variety (year of } \\
\text { development) }\end{array}$} & \multicolumn{1}{c}{ Breeders } \\
\hline Barley & $\begin{array}{l}\text { Austris (2006); Kornelia } \\
\text { (2012) }\end{array}$ & $\begin{array}{l}\text { M. Bleidere, S. Kalininina, } \\
\text { I. Rashal (Rašals), D. Grauda }\end{array}$ \\
Winter wheat & $\begin{array}{l}\text { Talsis (2009), Edvins } \\
(2010),\end{array}$ & $\begin{array}{l}\text { V. Strazdina, M. Ceraukste } \\
\text { Spring wheat }\end{array}$ \\
& Robijs (2008) & $\begin{array}{l}\text { V. Strazdiña, M. Ceraukste, } \\
\text { I. Rashal (Rašals), D. Grauda }\end{array}$
\end{tabular}

Over the past six years, the Breeding Department of the Institute filed four wheat and barley varieties for registration. The wheat varieties 'Fredis' and 'Uffo' are also registered in Estonia, while the variety 'Robijs' is undergoing examination of its value for cultivation and use in Lithuania (Strazdina, 2010).

Starting from 2009, the breeders of Stende have participated in a project on the Development, Improvement and Practical Application of Technologies for the Breeding of Environmentally Friendly and Sustainable Crop Varieties, which is co-financed by the European Social Fund (the managing body of the project is the State Priekuli Plant Breeding Institute). In 2010, the barley breeder Māra Bleidere received a $\mathrm{PhD}$ in Agricultural Science, following the defence of her promotion thesis on the grain quality as a selection criterion in barley breeding. The breeders' cooperation partners in other countries are Boreal in Finland, Limagrain in Germany, Jõgeva Plant Breeding Institute in Estonia, Institute of Agriculture of Lithuanian Research Centre for Agriculture and Forestry, Scientific Practical Centre of the NAS of Belarus for Arable Farming and others. Cooperation between the State Stende Cereal Breeding Institute and scientists from the Laboratory of Plant Genetics, Institute of Biology, University of Latvia, in the field of biotechnology methods in breeding has delivered a good outcome: two new varieties have been registered. As a result, the Latvian

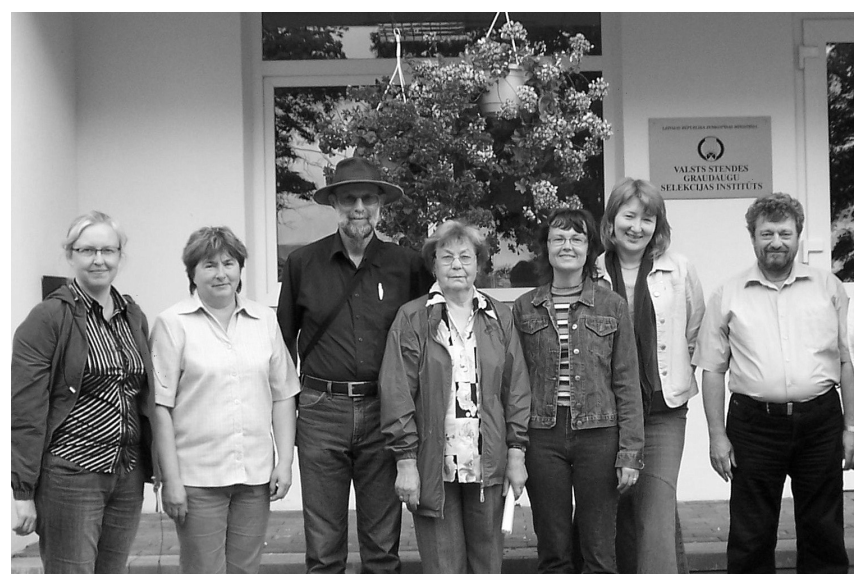

Colleagues from Canada and UL Institute of Biology are visiting Stende, from the left: Dr. D. Grauda (UL), wheat breeder V. Strazdina, Dr. D.E. Falk (Canada), barley breeders Prof. I. Belicka and M. Bleidere, Director of the Institute and oat breeder Dr. S. Zute, Prof. I. Rashal (Rašals) (UL) (2008). 
Academy of Sciences has awarded the diploma for Latvian Scientific Achievement in Practical Science for breeding the barley variety 'Austris' (2009) and the spring wheat variety 'Robijs' (2011).

Today, the seed of 14 varieties created at Stende are offered to Latvian farmers, along with conventional and organic seeds of potato and other crop species. Around 150 tons of cereal seeds and 100 tons of potato seeds are prepared at Stende each year.

In 2007-2009, the scientists of the Institute participated in the implementation of the state research programme in agrobiotechnology and conducted studies requested by the Ministry of Agriculture on cereal growing technologies applied on Latvian farms and use of cereals for heat production, as well as the studies funded by the Latvian Council of Science regarding the use of various catch crops in organic farming. The Ministry of Education and Science supported market-oriented research projects for the acquisition of high-quality oats to be used in food production (in partnership with A/S "Rigas Dzirnavnieks") and for the use of by-products of pharmaceutical industry in rape cultivation (in partnership with $\mathrm{A} / \mathrm{S}$ Grindeks).

The topics of research include not only the agricultural sector, but also cover other sectors, such as food science, medicine, engineering, etc. The year 2010 marked the start of two research projects co-financed by the European Regional Development Fund: Assessment of the Potential and Development of Varieties of Cereal Species of Local Origin for Specific Dietary Food Production (No. 2DP/2.1.1.1.0/10/ APIA/VIAA/083, in partnership with the Centre of Food Chemistry of the Faculty of Chemistry of the University of Latvia and the Faculty of Food Technology of Latvia University of Agriculture) and Study of Organic Product Extracts and Their Effects on Crop Production (No. 2DP/ 2.1.1.1.0/10/ APIA/VIAA/082, in partnership with the Institute of Agrobiotechnology of Latvia University of Agriculture, Institute of Biology of the University of Latvia and the Latvian Plant Protection Research Centre).

In 2010, ten research centres of national importance were established in Latvia, which combined the leading advanced scientific institutions in joint research in key sectors of the country's economy. The State Stende Cereal Breeding Institute became one of the five members of the National Research Centre of Use of Agricultural Resources and Food.

In March of 2012, the Research Council of the Institute elected a new director, Inga Jansone who was the head of the Agro-Ecological Research Department. This year, the breeders filed for registration the new hull-less barley variety 'Kornelia', and the official testing for the winter wheat variety 'Edvin' are scheduled for completion in autumn. Three new scientists of the Institute are conducting their doctoral studies at Latvia University of Agriculture. This year, an investment project co-financed by the European Regional Development Fund was started, which was aimed at modernisation of the Institute's laboratories and greenhouses.

The ninety years that have elapsed show that the scientists and breeders of Stende have continuously made a significant contribution to Latvian science and agriculture. Historical events and social developments have often created radical changes in the routine operations of the first breeding station, yet the key lines of the activities of this research centre - breeding, seed production and crop growing technologies investigation - have reamined unaffected. The traditions of scientific work that were started by J. Lielmanis, E. Bērziñš and N. Konrāds at Stende many years ago are now genuinely cherished and developed by the new team working at the Institute.

\section{REFERENCES*}

Anonīms (1923). Lauksaimniecības departamenta gada grāmata. 1. gads [Yearbook of Agriculture Department. Year 1]. Rīga: Lauksaimniecības departaments. 545 lpp. (in Latvian).

Anonīms (1960). Stendes selekcijas un uzmègéinājumu stacija 1960. gadā [Stende Breeding and Research Station in 1960]. LPSR LM Latvijas zinātniski pētnieciskais institūts. 60 lpp. (in Latvian).

Anonīms (2004). Laukaugu selekcionāram Nikolajam Konrādam simts gadi [Centennial of Crop Breeder Nikolajs Konrāds]. Valsts Stendes selekcijas stacija. 48 lpp. (in Latvian).

Anonīms (2007). Emīls Bērzinš — pirmais Stendes selekcionārs [Emīls Bērziņš - the First Breeder in Stende]. Valsts Stendes graudaugu selekcijas institūts. 68 lpp. (in Latvian).

Belickis, M. (1975). Stendes selekcijas un izmēǵinājumu stacijas izaugsme [Growth of the Stende Breeding and Experimental Station]. Grām.: Druvu briedumam (7.-14. lpp.). Rīga: Zvaigzne.

Bērziņš, E. (1936). Linu deǵenerācija eksperimentālajā apgaismojumā [Degeneration of flax in Experimental Lighting]. Rīgā: Latvijas Agronomu biedrība. 20 lpp. (in Latvian).

Celma, I., Kaḷiņina, S., Kalmanis, Z., Krotovs, M., Strazdiņa, V., Zute, S. (red.). (2002). Valsts Stendes selekcijas stacija laiku lokos. No 23. aprīla 1922. gadā lìdz mūsdienām [State Stende Breeding in the Course of Time. From 23 April 1922 until nowadays]. Valsts Stendes selekcijas stacija. 123 1pp. (in Latvian).

Holms, I. (red.) (1992). Laukaugu selekcija Latvijā [Crop Breeding in Latvia]. Rīga: Avots. 192 lpp. (in Latvian).

Kalmanis, Z. (2000). Jurijs Garbars. Grām.: Vārpu vainaga zīmēe (28.-29. lpp.). Valsts Stendes graudaugu selekcijas institūts (in Latvian).

Kalmanis, Z. (2001). Zelma Strumpe. Grām.: Vārpu vainaga zīmēe II (16.-18. lpp.). Valsts Stendes selekcijas stacija (in Latvian).

Kalmanis, Z. (2003). Raisa Kude. Grām.: Vārpu vainaga zīmēe III (9.-10. lpp.). Valsts Stendes selekcijas stacija (in Latvian).

Lielmanis, J. (1939) Pākšaugu audzēšanas izmēgéinājumi Stendes selekcijas stacijā. Izvilkums no Lauksaimniecības izmēǵinājumu un pētījumu žurnāla $N r$. 1. [Legume growth trials in Stende Breeding Station. Excerpt from the Agriculture trial and research journal No.1]. Rīga. 35.-89. lpp. (in Latvian).

Lielmanis, J., Bērziņš, E., Garbars, J. (1931). Selekcijas un izmēgóinājumu darbi Valsts Stendes selekcijas stacijā [Breeding and experimental works at State Stende Breeding Station]. Rīga: Valters un Rapa. 289 lpp. (in Latvian).

* Additional material about history of the State Stende Cereal Breeding Institute, including reports on scientific research work for different periods, could be found on the home page of the institute: http://www.stendeselekcija.lv 
Lielmanis, J. (1935). Stendes selekcijas stacijas sasniegumi [Achievements of the Stende Breeding Station]. Zemkopis, Nr. 19, 424.-425. 1pp. (in Latvian).
Lielmanis, J., Bērziņš, E. u.c. (1947). Stendes selekcijas stacijas 25 darbības gadi [25 Years of Operation of the Stende Breeding Station]. Stendes selekcijas stacija. 354 lpp. (in Latvian).

Stazdina, V. (2010). Kviěsu selekcija Latvijā [Wheat Breeding in Latvia]. Valsts Stendes graudaugu selekcijas institūts. 95 lpp. (in Latvian).

\section{VALSTS STENDES GRAUDAUGU SELEKCIJAS INSTITŪTS — NO PIRMSĀKUMIEM LĪDZ ŠODIENAI}

Lauksaimniecības zinātne ir cieši saistīta ar katra reǵiona apstākḷiem un attīstības īpatnībām. Valsts Stendes selekcijas stacija kā pirmā neatkarīgās Latvijas valsts selekcijas stacija dibināta pirms deviṇdesmit gadiem. Tās uzdevums bija celt valstī lauksaimniecību, atlasot Latvijas apstākḷiem piemērotākās laukaugu škiines, nodrošinot zemniekus augstas kvalitātes sēklām un ar zināšanām par šo škirṇu audzēšanu. Pagājušo gadu laikā ir mainījušās politiskās varas, saimniekošanas formas un zinātniskās iestādes juridiskais statuss un nosaukumi. Stendē strādājuši izcili zinātnieki un agronomi J. Lielmanis, E. Bērziňš, J. Garbars, N. Konrāds, R. Kude, I,. Celma, M. Gruntiņa u.c., kuri zinātnei un selekcijai veltījuši visu savu darba mūžu. No 2006. gada lauksaimniecības zinātnes centra nosaukums Stendē ir Valsts Stendes graudaugu selekcijas institūts. Stabilas tradīcijas graudaugu selekcijā un sadarbībā ar Latvijas lauksaimniekiem, vairāku zinātnieku paaudžu uzkrātās zināšanas un pieredze — tās ir stabilās vērtības, kas zinātnes centra pastāvēšanu nodrošinājušās visos laikos. Stendes selekcionāru lielākais devums ir 65 jaunizveidotās piecpadsmit laukaugu sugu šḳirnes, no kurām mieži 'Abava', ziemas kvieši 'Fredis', vasaras kvieši 'Uffo' ir labi pazīstamas ne tikai Latvijā, bet arī aiz tās robežām. Stendē zinātnieku paveikto atzinīgi novērtē lauksaimnieki praktiḳi un lauksaimniecības politikas veidotāji 